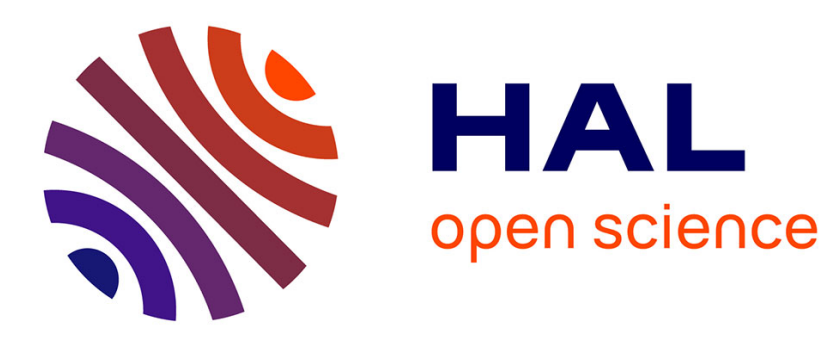

\title{
Genetic and environmental variation in wood properties of Acacia melanoxylon
}

\author{
Gordon Bradbury, Brad Potts, Chris Beadle
}

\section{To cite this version:}

Gordon Bradbury, Brad Potts, Chris Beadle. Genetic and environmental variation in wood properties of Acacia melanoxylon. Annals of Forest Science, 2011, 68 (8), pp.1363-1373. 10.1007/s13595-0110115-x . hal-00930684

\section{HAL Id: hal-00930684 https://hal.science/hal-00930684}

Submitted on 1 Jan 2011

HAL is a multi-disciplinary open access archive for the deposit and dissemination of scientific research documents, whether they are published or not. The documents may come from teaching and research institutions in France or abroad, or from public or private research centers.
L'archive ouverte pluridisciplinaire HAL, est destinée au dépôt et à la diffusion de documents scientifiques de niveau recherche, publiés ou non, émanant des établissements d'enseignement et de recherche français ou étrangers, des laboratoires publics ou privés. 


\title{
Genetic and environmental variation in wood properties of Acacia melanoxylon
}

\author{
Gordon J. Bradbury • Brad M. Potts • Chris L. Beadle
}

Received: 5 April 2011 / Accepted: 11 July 2011 /Published online: 4 August 2011

(C) INRA and Springer Science+Business Media B.V. 2011

\begin{abstract}
- Context Australian blackwood (Acacia melanoxylon), is a fast-growing, high-quality, appearance-grade timber species native to eastern Australia. Some of its key wood properties are percentage heartwood, heartwood colour, basic density, wood stiffness and green moisture content. Variation in these properties affects log value, processing and marketing.

- Aims This study aims to understand how genetics and environment affect these wood properties.

- Methods Stem cores were taken from 16 open-pollinated blackwood families from the island of Tasmania, Australia, which were planted across three 18-year-old progeny trials. - Results Significant effects of genetics, environment and their interaction (GxE) were found for many of the wood properties examined. Both broad-scale and local environmental effects were apparent, with local effects associated with competition and/or allelopathy from a Eucalyptus globulus nurse crop present in one trial. No significant correlation of growth rate (i.e. stem diameter) with wood
\end{abstract}

Handling Editor: Jean-Michel Leban

G. J. Bradbury $(\bowtie) \cdot$ B. M. Potts

School of Plant Science,

University of Tasmania,

Private Bag 55,

Hobart, Tasmania 7001, Australia

e-mail: gordonb0@utas.edu.au

C. L. Beadle

CSIRO Ecosystem Sciences and Cooperative

Research Centre for Forestry,

Private Bag 12,

Hobart, Tasmania 7001, Australia

C. L. Beadle

Tasmanian Institute for Agricultural Research,

Private Bag 55,

Hobart, Tasmania 7001, Australia properties was detected at the family level apart from a positive relationship with heartwood width. At the phenotypic level, there were many significant correlations including growth rate with heartwood width, but not with basic density, or wood stiffness measured as standing tree time of flight. Faster growing trees had yellower heartwood while trees with higher basic and green densities tended to have darker, redder and less yellow heartwood.

- Conclusion Both genetic and environment factors affect key wood properties of Australian blackwood, but in most cases these effects were independent of growth rate.

Keywords Blackwood - Genetics · Wood colour Tonewood

\section{Introduction}

Blackwood has been recognised in Australia as a premium appearance-grade hardwood since the early European settlement. It is one of the most widely distributed tree species in eastern Australia (Cowan and Maslin 2001). The species has been planted as an exotic and managed for its timber values in South Africa, New Zealand, Vietnam, China and Chile. Blackwood timber is of medium density, with excellent drying, working and finishing properties. It has pale cream sapwood with a generally dark heartwood colour range (Bradbury et al. 2010b). It occasionally exhibits strong figure in the grain such as fiddleback or wavy grain. The timber is used in a range of high value end uses including veneer, musical instruments, furniture, joinery, flooring and craft.

Log diameter, percentage heartwood and heartwood colour are key factors determining the value of blackwood logs (de Zwaan 1982), while traits such as heartwood colour, wood density and stiffness affect many uses such as 
furniture (Lambert 2004) and tonewood quality (Bucur 2006). Blackwood tonewood is predominantly used for the back, sides and necks (Evans 2007) and occasionally as soundboard material in acoustic guitars. Timber used for soundboards traditionally has good stiffness to density ratio characteristics, that allow for good sound propagation, which are mostly associated with softwoods such as spruce (Picea sp.) and fir (Abies sp.). Back-and-side material generally has high visual appeal, higher density, good tonal acoustic properties (high velocity of sound) and good working and heat bending ability (Haines 2000). Density, strength, hardness and colour are also key requirements of timber used for flooring and furniture applications.

The present paper focuses on understanding the relative importance of the genetic and environmental effects on blackwood non-colour wood properties, and their intercorrelations, especially with growth rate and heartwood colour. Non-colour wood properties of blackwood have been widely reported (Kingston and Risdon 1961; Bolza and Kloot 1963; Haslett 1986), based mostly on limited numbers of samples, often of unknown age and origin, and using varying sampling and measuring methodologies. Despite apparent variation in many wood properties, little attention has been given to genetic and environmental sources of variation, in spite of their potential effects on blackwood selection, breeding and utilisation. In this study family based progeny grown across three trials reported in Bradbury et al. (2010a), were used to assess the extent of genetic and environmental variation and their interactions on wood properties in blackwood.

\section{Materials and methods}

\subsection{Trials and genetic material}

Three 18-year-old trials containing 16 open-pollinated Tasmanian blackwood families were selected (Bradbury et al. 2010a). One trial was located at Meunna (266/2/2) in north-west Tasmania while two were located at Virginstow in northern Tasmania (Virginstow, 266/4/1 and 266/4/2). The families in each trial were planted in a random complete block design. Two trials of pure blackwood (Meunna, 266/2/2 and Virginstow, 266/4/2) were planted with five blocks, each comprising single-family line plots of 20 trees. The spacing was $3.0 \mathrm{~m}$ between rows and $4.2 \mathrm{~m}$ within rows. The third trial, Virginstow (266/4/1) involved plantings of the same 16 blackwood families in two blocks but with an inter-planted nurse crop of one of the main plantation eucalypts grown in this area, Eucalyptus globulus. In this trial, family plots were of approximately 0.2 ha in area, with spacing of $3.0 \mathrm{~m}$ between all rows, and 4.2 and $2.1 \mathrm{~m}$ within rows for the blackwood and eucalypt, respectively, with alternate rows of the single blackwood family and E. globulus, and a minimum of seven rows of blackwood per family plot. Plots varied in length and width but there were approximately 80 blackwood trees in each plot. The nurse crop was included as it was expected to enhance blackwood survival and form. The two Virginstow trials were spatially intermixed with planting bays of the nurse crop trial alternated with planting bays of the pure blackwood trial, so that the primary difference between the trials was the presence of the nurse crop. None of the trials had received any thinning or pruning treatment. Meunna has deep, fertile, kraznozem soils on Tertiary basalt (soil type 16.1, Grant 1995), high rainfall (1,600 $\left.\mathrm{mm} \mathrm{year}^{-1}\right)$ and is at an altitude of $320 \mathrm{~m}$ and can be regarded as a good site for growing commercial blackwood. Virginstow has sandy loam over clay soils on Precambrian sandstone, slate and phyllite, of low fertility (soil type 4.1, Grant 1995) and lower rainfall $\left(930 \mathrm{~mm} \mathrm{year}^{-1}\right)$, is at an altitude of $160 \mathrm{~m}$ and can be regarded as a poor blackwood site.

\subsection{Sampling and measurement}

Twelve trees from each of the 16 seedlots were selected from across two-to-three blocks in each trial for measurement and sampling. The blocks excluded from sampling were those where survival was low (Virginstow, 266/4/2) or blackwood wildlings meant pedigrees could not be assured (Meunna, 266/2/2). The $12 \mathrm{~mm}$ diameter stem cores were taken at breast height $(1.3 \mathrm{~m})$ in a north-south direction from each tree, with no cores taken from trees with a diameter breast height over bark (DBHOB) of $<10 \mathrm{~cm}$. The standard height and orientation of the core sampling was adopted for consistency amongst trees. Stem eccentricity was deemed to be minimal. The 10-cm DBHOB limited was applied for practical reasons (difficulty of mechanically coring small trees) and to maximise the possibility of heartwood in the samples for colour analysis. Trees with DBHOB of $\geq 10 \mathrm{~cm}$ accounted for $64 \%$ of all trees in the 16 families in the three trials. Other than the DBHOB criterion, trees were randomly selected from each family plot.

For each tree stem DBHOB was measured, and standing tree time-of-flight (TOF) was estimated on a one metre length of the lower stem using a Fakopp transit timer. Standing tree TOF uses acoustic waves to measure outerwood stiffness in trees (Grabianowski et al. 2006). It is used where selection and breeding for improved wood stiffness is required. Four TOF measurements were made of each tree, two each from the north and south sides. Stem core height was slightly adjusted where necessary to avoid including branch traces or other obvious defects in the cores. Cores were labelled and wrapped in plastic film before being refrigerated. 
In the laboratory, whole green cores were measured for weight, and volume using the water displacement method, total sapwood width (the sum of all sapwood from both sides of the core), heartwood width, percentage heartwood (by area) and the count of visible annual growth rings within the sapwood. Cores were then oven-dried at $105^{\circ} \mathrm{C}$ for 2 days. Oven-dried whole core weight and volume were then measured. For colour measurement, the dried cores were mounted into routed grooves in boards of Pinus radiata using polyvinyl acetate glue and put through a commercial drum sander to remove half of each core and expose a dressed radial surface. Colour was measured using a Minolta CR400 Chroma Meter and the CIELAB colour space (Wyszecki and Stiles 1982) using the C illuminant and the $2^{\circ}$ standard observer (Bradbury et al. 2010b).

In brief, the CIELAB colour space is an international standard colour space which describes all the visible colours to three coordinates representing the lightness of the colour $\left(L^{*}\right)$, its position between red and green $\left(a^{*}=\right.$ redness) and its position between yellow and blue $\left(b^{*}=\right.$ yellowness). Colour measurements of the heartwood were taken in 8-mm radial increments from the pith to the visible heartwood-sapwood boundary on either side of the pith, with care to avoid including sapwood in the heartwood colour data. Two single-sapwood colour measurements were taken from each core, one either side of the pith centred between the heartwood-sapwood boundary and the outer edge of the core under bark. Each sanded core was also assessed for the presence of any figured grain (fiddleback, birdseye etc.).

Derived whole core traits were basic density (basic density $=$ oven-dry mass/green volume; $\mathrm{kg} \mathrm{m}^{-3}$ ), green density (green density=green mass/green volume; $\mathrm{kg} \mathrm{m}^{-3}$ ) and green moisture content $(\mathrm{GMC}=100 *$ (green mass - oven-dry mass)/oven-dry mass; \%). The Fakopp ( $\mu$ s) values were converted to TOF $\left(\mathrm{m} \mathrm{s}^{-1}\right)$ using the mean of the four Fakopp measurements. For each core, the mean heartwood and sapwood $L^{*}, a^{*}$ and $b^{*}$ were calculated. The difference between two colours can be measured in the CIELAB colour space using the formula $\Delta E 76=\sqrt{\Delta L^{2}+\Delta a^{2}+\Delta b^{2}}$ (Wyszecki and Stiles 1982). Within-core heartwood colour variation was determined by calculating the difference $(\Delta E 76)$ between all heartwood colour measurements. For each core, both the mean and maximum $\Delta E 76$ were used as measures of heartwood colour variation. For each core, the difference between the mean heartwood and mean sapwood colours was also calculated (Bradbury et al. 2010b).

\subsection{Data analysis}

The significance of trial, seedlot and their interaction on DBHOB and wood properties was tested by fitting a mixed linear model to stem core data using Proc MIXED of SAS (version 9.1, SAS Institute Inc. 2004). The model fitted was:

$$
\begin{aligned}
Y= & \text { TRIAL }+ \text { SEEDLOT + TRIAL.SEEDLOT } \\
& + \text { BLOCK }(\text { TRIAL })+\text { PLOT + RESIDUAL }
\end{aligned}
$$

where $Y$ is the vector of observations, TRIAL is the fixed trial effect, SEEDLOT is the fixed seedlot effect and TRIAL. SEEDLOT is the fixed trial by seedlot interaction effect. BLOCK(TRIAL) is the random block-within-trial effect and PLOT is the random plot-within seedlot within-trial effect. In a separate analysis, stem diameter (DBHOB) was included as a covariate added to the linear model as a fixed effect to test what effect, if any, growth rate had on the wood property traits. No significant trial by covariate or seedlot by covariate interactions were detected in preliminary analyses, thus these terms were not included in the final model. The random REP (TRIAL) effect was used as the error to provide an approximate test of the fixed TRIAL effect, and when significant the Tukey-Kramer test for multiple comparisons was used to determine which trials were significantly different $(p<0.05)$. The SEEDLOT and TRIAL.SEEDLOT effects were tested using the random PLOT term as the error.

To calculate Pearson's correlations between traits at a seedlot (i.e. genetic) and phenotypic level, the tree-level data were firstly standardised using PROC STANDARD of SAS such that each site had a mean of zero and a standard deviation of one. Overall seedlot arithmetic means for each trait were then calculated and the Pearson's correlations amongst traits calculated using these means with PROC CORR of SAS. The phenotypic correlations were calculated on the standardised tree-level data and represent the pooled, within-trial phenotypic correlations amongst traits. In addition to pair-wise significance levels, a Bonferroni adjustment for a $p=0.05$ level of significance across all comparisons within a correlation type was also used $(\mathrm{p}<0.00064)$. The Bonferroni adjustment is used to adjust the significance level to avoid type I (false-positive) errors when making multiple comparisons (Quinn and Keough 2002).

\section{Results}

\subsection{Genetic and environmental variation}

\subsubsection{Stem diameter and figured grain}

The mean diameter of the sampled trees was $15.3 \pm 4.2 \mathrm{~cm}$ (Table 1). Nurse crop trial Virginstow $(266 / 4 / 1)$ had the lowest mean diameter of $13.8 \mathrm{~cm}$ while Meunna (266/2/2) had the highest at $16.0 \mathrm{~cm}$. However, the difference between trials was not statistically significant (Table 1). This was also the case when all trees from the 16 seedlots 
were measured, rather than the smaller sample of larger ( $\geq 10 \mathrm{~cm}$ diameter) trees used in this study (Bradbury et al. 2010a). The differences in stem diameter between seedlots based on the $\geq 10$-cm subsample were significant, but there was no significant trial by seedlot interaction (Table 1). Only one stem core displayed traces of figured (fiddleback) grain character on the radial surface.

\subsubsection{Heartwood and sapwood}

Mean $( \pm \mathrm{SD}$ ) heartwood width was $86.7 \pm 33.2 \mathrm{~mm}$ (range, 0 to $206 \mathrm{~mm}$ ), mean total sapwood width was $53.1 \pm 17.5 \mathrm{~mm}$ (range, 17 to $168 \mathrm{~mm}$ ) and the mean percentage heartwood was $38.6 \pm 13.4 \%$ (range, $0 \%$ to $77 \%$ ). Sapwood annual ring count ranged from 3 to 12 years with a mean of 6.5 but could only be assessed on $39 \%$ of the cores due to indistinct annual rings. Trial had no significant effect on any of these three traits. Seedlot had a significant effect on percentage heartwood and sapwood width (Table 1). However, despite a significant seedlot effect on stem diameter there was no significant seedlot effect on the absolute amount of heartwood. Therefore the significant difference in stem diameter was due to differences between the seedlots in sapwood width. This trend was consistent with the percentage heartwood being significantly negatively correlated with sapwood width at the seedlot level but not with heartwood width (Table 2). When diameter was fitted as a covariate, there was a significant difference between seedlots in the percentage heartwood $\left(F_{15}, 71=3.6 ; p<0.001\right)$, indicating that, at least in a linear sense, growth rate alone did not explain the difference in percentage heartwood between seedlots. There was no significant trial by seedlot interaction effects on any of these three traits.

\subsubsection{Green/basic density and green moisture content}

Whole core green density had a mean of $1,001 \pm 105 \mathrm{~kg} \mathrm{~m}^{-3}$ (range, 584 to $1,160 \mathrm{~kg} \mathrm{~m}^{-3}$ ), while whole core basic density had a mean of $488 \pm 51 \mathrm{~kg} \mathrm{~m}^{-3}$ (range, 332 to $635 \mathrm{~kg} \mathrm{~m}^{-3}$ ). Both traits showed significant trial and seedlot effects, as well as significant trial by seedlot interactions (Table 1). The significant trial effects were due to the nurse crop trial Virginstow (266/4/1) having significantly lower green density than the other two trials, and Meunna (266/2/ 2) having significantly lower basic density than either of the Virginstow trials (Table 3). The significant interaction effects on basic density were due to changes in rank between seedlots across trials, with two seedlots (1M and 7B) showing particularly marked changes in rank in the nurse crop trial Virginstow (266/4/1) (Fig. 1). However, many seedlots retained their basic density ranking across the trials; especially between the pure blackwood trials at Meunna (266/2/2) and Virginstow (266/4/2), demonstrating the significant seedlot main effect on this trait.

Whole core GMC had a mean of $106 \pm 22 \%$ (range, $51 \%$ to $176 \%$ ). There were significant trial and seedlot effects on GMC and no significant interaction effects (Table 1). The trial effect was very strong with significant differences
Table 1 Stem core properties together with $F$ values and significances of the fixed terms from the mixed model analysis

${ }^{*} p<0.05 ; * * p<0.01 ; * * *$ $p<0.001$, significance levels

\begin{tabular}{|c|c|c|c|c|c|}
\hline & Mean & $\mathrm{SD}$ & $\begin{array}{l}\text { Trial } \\
F_{2,6}\end{array}$ & $\begin{array}{l}\text { Seedlot } \\
F_{15,71}\end{array}$ & $\begin{array}{l}\text { Trial x Seedlot } \\
F_{30,71}\end{array}$ \\
\hline Stem diameter $(\mathrm{cm})$ & 15.3 & 4.2 & 3.6 & $1.9^{*}$ & 0.4 \\
\hline Sapwood width (mm) & 53.1 & 17.5 & 2.9 & $4.1 * * *$ & 0.9 \\
\hline Heartwood width (mm) & 86.7 & 33.2 & 1.7 & 1.1 & 0.7 \\
\hline Heartwood $(\%)$ & 38.6 & 13.4 & 1.7 & $2.1^{*}$ & 1.0 \\
\hline Green density $\left(\mathrm{kg} \mathrm{m}^{-3}\right)$ & $1,000.8$ & 104.7 & $22.6^{* *}$ & $2.4^{* *}$ & $2.0 * *$ \\
\hline Basic density $\left(\mathrm{kg} \mathrm{m}^{-3}\right)$ & 488 & 51 & $9.7 *$ & $4.5^{* * *}$ & $1.8^{*}$ \\
\hline Green Moisture Content (\%) & 106.3 & 22.5 & $83.4 * * *$ & $2.6^{* *}$ & 1.6 \\
\hline Time of Flight $\left(\mathrm{m} \mathrm{s}^{-1}\right)$ & 3,803 & 309 & 3.0 & $4.2 * * *$ & $2.5^{* *}$ \\
\hline Heartwood lightness $\left(L^{*}\right)$ & 62.7 & 4.8 & $14.4 * *$ & $4.0 * * *$ & $2.6^{* *}$ \\
\hline Heartwood redness $\left(a^{*}\right)$ & 9.5 & 1.4 & $11.6 * *$ & $4.0 * * *$ & $2.0 * *$ \\
\hline Heartwood yellowness $\left(b^{*}\right)$ & 20.3 & 1.2 & $18.2 * *$ & $4.2 * * *$ & $3.6^{* * *}$ \\
\hline Sapwood lightness $\left(L^{*}\right)$ & 82.2 & 3.5 & 4.4 & 1.4 & 0.9 \\
\hline Sapwood redness $\left(a^{*}\right)$ & 3.0 & 1.1 & $6.3^{*}$ & 1.1 & 1.2 \\
\hline Sapwood yellowness $\left(b^{*}\right)$ & 15.2 & 1.4 & 0.2 & 0.9 & 0.9 \\
\hline $\begin{array}{l}\text { Mean within-core heartwood } \\
\text { colour variation }(\Delta E)\end{array}$ & 4.5 & 1.6 & 3.0 & 1.6 & 1.1 \\
\hline $\begin{array}{l}\text { Maximum within-core heartwood colour } \\
\text { variation }(\Delta E)\end{array}$ & 10.9 & 4.7 & 0.5 & 1.2 & 1.0 \\
\hline $\begin{array}{l}\text { Sapwood to heartwood mean } \\
\text { colour difference }(\Delta E)\end{array}$ & 21.4 & 4.4 & 0.3 & $2.9^{* *}$ & $2.0 * *$ \\
\hline
\end{tabular}




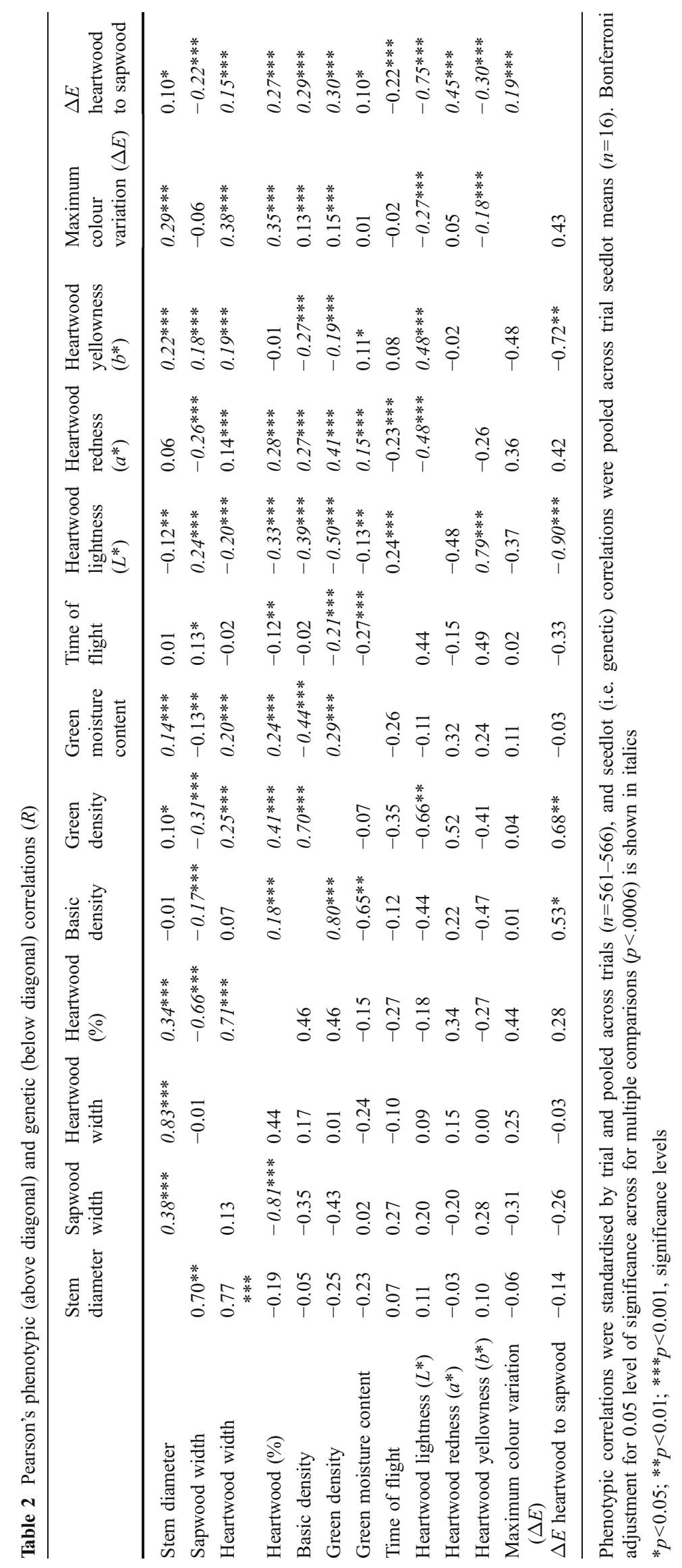


Table 3 Mean stem core values for the three trials for traits where significant trial effects were observed

Values in the same row having the same letter do not differ significantly $(p<0.05)$ following the Tukey-Kramer adjustment

\begin{tabular}{llll}
\hline & \multicolumn{2}{l}{ Trial } & \\
\cline { 2 - 4 } & Meunna 266/2/2 & Virginstow 266/4/1 (nurse crop) & Virginstow 266/4/2 \\
\hline Green density $\left(\mathrm{kg} \mathrm{m}^{-3}\right)$ & $1,044 \mathrm{a}$ & $924 \mathrm{~b}$ & $1,020 \mathrm{a}$ \\
Basic density $\left(\mathrm{kg} \mathrm{m}^{-3}\right)$ & $465 \mathrm{~b}$ & $497 \mathrm{a}$ & $502 \mathrm{a}$ \\
Green moisture content $(\%)$ & $126 \mathrm{a}$ & $86 \mathrm{c}$ & $104 \mathrm{~b}$ \\
Heartwood lightness $\left(L^{*}\right)$ & $61.7 \mathrm{~b}$ & $64.3 \mathrm{a}$ & $61.8 \mathrm{a}, \mathrm{b}$ \\
Heartwood redness $\left(a^{*}\right)$ & $9.6 \mathrm{a}, \mathrm{b}$ & $9.1 \mathrm{~b}$ & $9.8 \mathrm{a}$ \\
Heartwood yellowness $\left(b^{*}\right)$ & $20.8 \mathrm{a}$ & $19.7 \mathrm{~b}$ & $20.8 \mathrm{a}$ \\
Sapwood redness $\left(a^{*}\right)$ & $3.3 \mathrm{a}$ & $2.5 \mathrm{~b}$ & $3.0 \mathrm{a}, \mathrm{b}$ \\
\hline
\end{tabular}

between all three trials (Table 2). Mean GMC was greatest at Meunna (266/2/2), the highest rainfall trial and lowest in the nurse crop trial Virginstow (266/4/1) (Table 3). When fitted as a covariate in the mixed model, stem diameter had a significant positive effect on both green density $\left(F_{1,440}=\right.$ $7.6 ; p=0.006)$ and $\operatorname{GMC}\left(F_{1,440}=12.2 ; p=0.0005\right)$ but not on basic density $\left(F_{1,440}=0.0 ; p=0.948\right)$. Similarly, increasing percentage heartwood increased green density $\left(F_{1,440}=75.86 ; p<0.001\right)$, GMC $\left(F_{1,440}=34.4 ; p<0.001\right)$ and basic density $\left(F_{1,440}=13.5 ; p<0.001\right)$. Fitting either variable in the model as covariate had no effect on the significance of the trial, seedlot or interaction effects on green and basic density, or GMC.

\subsubsection{Time of flight}

The mean standing tree TOF was $3,803 \pm 309 \mathrm{~ms}^{-1}$ (range, 2,835 to $5,025 \mathrm{~ms}^{-1}$ ). There was a significant seedlot effect

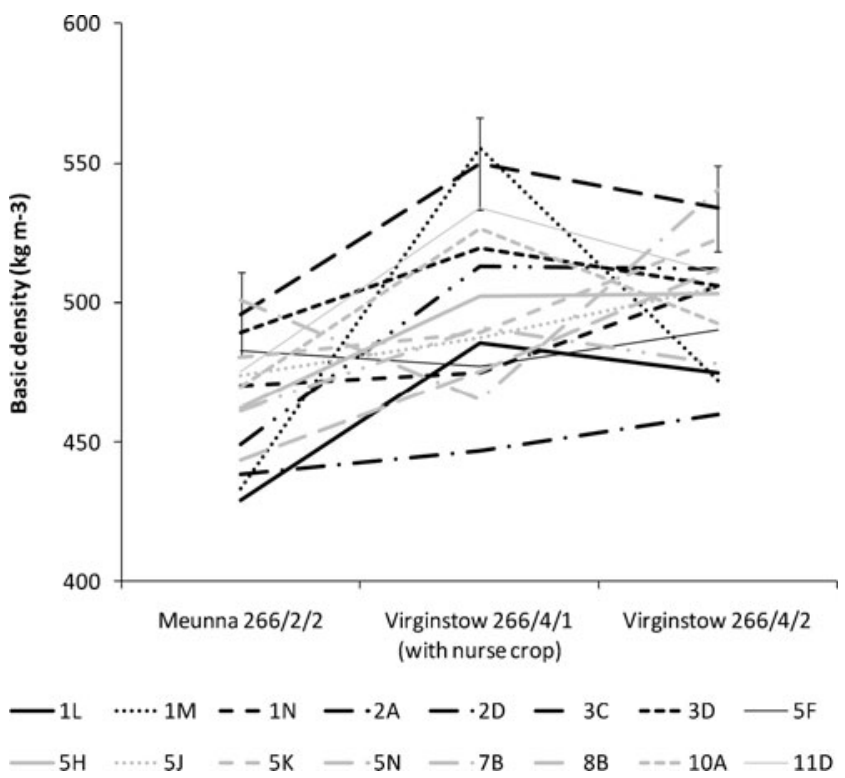

Fig. 1 Significant trial by seedlot interaction effects for basic density. Typical standard errors for each trial are shown but displayed on only one seedlot mean for the sake of simplicity and a significant interaction effect on TOF (Table 1). The significant interaction effect was due to both changes in seedlot ranking between trials as well as changes in variation in TOF, particularly in the nurse crop trial Virginstow (266/4/1).

\subsubsection{Heartwood colour}

Significant trial, seedlot and interaction effects on all mean heartwood colour traits were found (Table 1), consistent with the results of Bradbury et al. (2011) where individual colour measures were analysed using a mixed model which fitted a cubic spline to model within-core variation. The significant trial effect was due to the heartwood from the nurse crop trial Virginstow (266/4/1) being lighter, less red and less yellow than the heartwood from the other trials (Table 3). Sapwood colour showed little trial or seedlot variation (Table 1). The only significant effect detected was a trial effect on sapwood redness, which was due to the nurse crop trial Virginstow (266/4/1) having less red sapwood, consistent with the trend in heartwood (Table 3). There were no significant trial, seedlot or interaction effects on either within-core mean or maximum $\Delta E 76$ values (Table 1).

\subsection{Correlations}

At the phenotypic level within trials, correlations indicated that faster growing trees (i.e. stem diameter) had more sapwood and heartwood, greater percentage heartwood, and greater green moisture content (Table 2). However, at the seedlot level (i.e. genetic level) these correlations were only significant for sapwood and heartwood width, with faster growing families having more heartwood and sapwood (Table 2). There was no significant correlation between growth rate and basic density or TOF at either the phenotypic or seedlot level (Table 2). There were many significant correlations amongst the wood property traits at the phenotypic level but few at the seedlot level (Table 2). At the phenotypic level, TOF was weakly negatively 
correlated with GMC $(r=-0.27)$ and green density $(r=-0.21)$, but not basic density $(r=-0.02)$, despite basic and green density being positively correlated $(r=0.70)$. At the phenotypic level, heartwood colour was weakly correlated with diameter growth but was correlated with percentage heartwood, as well as basic and green densities. Faster growing trees tended to have darker $\left(L^{*}\right)$ and more yellow $\left(b^{*}\right)$ heartwood. However, when the joint correlation with percentage heartwood is accounted for by a partial correlation analysis, only the phenotypic correlation between diameter and heartwood yellowness was significant $\left(r_{\text {partial }}=0.24\right.$; $p<0.001)$. Trees with higher basic and green density tended to have darker $\left(L^{*}\right)$, more red $\left(a^{*}\right)$ and less yellow $\left(b^{*}\right)$ heartwood, however at the seedlot level these correlations were only significant between green density and heartwood $L^{*}$; these correlations remaining significant when the intercorrelation between percentage heartwood and basic density was accounted for by removing the effect of percentage heartwood using partial correlation analysis.

\section{Discussion}

\subsection{Genetic and environmental variation in wood properties}

A limited genetic and environmental sampling has shown that both genetics (seedlot) and environment (trial) can significantly affect many wood properties in blackwood. In many cases there were also significant interactions. These interactions usually involved changes in the ranking of seedlots, with most changes associated with differences in seedlot performance in the nurse crop trial, Virginstow (266/4/1).

The absolute amount of heartwood in blackwood was driven by growth rate. However, the relative amount of heartwood was related to variation in sapwood width, which has a genetic basis; this appeared to drive differences between seedlots in percentage heartwood. This suggests that improvements in both growth rate and percentage heartwood through genetic selection can be made independently. However, genetic differences in percentage heartwood may become less significant with increasing tree size/ age, as heartwood increases as a proportion of DBHOB. Percentage heartwood has also been shown to be under genetic control in other hardwood species including other Acacia species (Searle and Owen 2005) but not previously in blackwood.

If percentage heartwood and heartwood colour in blackwood is to be assessed by breeders, then it is important to understand at what tree size and age heartwood formation commences and can be first assessed. This also requires early age assessments being associated with harvest age measures (i.e. strong age-to-age correlations).
For breeders, these considerations affect the assessment and breeding-cycle times. Tree size rather than age may be more significant in the commencement of heartwood production in blackwood. Two previous studies of blackwoods of similar or younger ages have shown trees of larger stem diameter had greater percentage heartwood than the current study. A 10-year-old progeny trial had mean diameters of 16.6 to $20.5 \mathrm{~cm}$ with mean percentage heartwood of $42 \%$ to $52 \%$ (Nicholas et al. 1994); thinnings from a 17 -year-old silvicultural trial had a mean diameter of $24.1 \mathrm{~cm}$ and mean percentage heartwood of 54\% (Nicholas et al. 2007); the current study of 18-year-old blackwood had a mean diameter of $15.3 \mathrm{~cm}$ and mean percentage heartwood of $38.6 \%$. The best performing provenance in the 10 -year-old trial was the same as that used in the silvicultural trial, where only the smaller, thinning material was sampled. While this comparison is confounded by genetic and sampling effects, it does indicate that stem diameter may be the dominant factor controlling the initiation of heartwood production. This hypothesis needs to be tested with age-age correlations in percentage heartwood across a range of genetic material. No age-age correlations in percentage heartwood in blackwood or any other Acacia species are known.

Green and basic densities, GMC and stiffness estimated as TOF were within the ranges previously reported. Basic density range was similar to that in a 17-year-old silvicultural trial involving a single Tasmanian blackwood provenance (291-633 $\mathrm{kg} \mathrm{m}^{-3}$ ) (Nicholas et al. 2007). The variation in these wood traits, even within the limited range of material sampled in this study, highlights the issue of product consistency in blackwood, particularly the very low basic densities $\left(<400 \mathrm{~kg} \mathrm{~m}^{-3}\right)$ that may be associated with low strength and low hardness. The significant differences between seedlots for these traits indicates that genetic gains are possible, although the significant trial (excluding TOF) and GxE interaction effects (excluding GMC) show that greater understanding of the environmental factors affecting these traits is needed. Significant genetic variation in basic density has previously been found in blackwood (Nicholas et al. 1994) and other Acacia species (Searle and Owen 2005; Hai et al. 2007), with significant differences found between provenances (Hai et al. 2007). Much of the significant interaction effect on basic density in the current study was due to major reaction by a few seedlots (e.g. 1M and 7B) to conditions in nurse crop trial Virginstow (266/4/ 1), while most seedlots showed reasonable stability in ranking across the three trials (Fig. 1), demonstrating the significant genetic effect on basic density.

This was not the case with TOF where the significant interaction effects were the result of changes in order of rank across the trials for many seedlots, as well as increased variation in TOF between the seedlots in the nurse crop trial 
compared with the two pure blackwood trials. Basic density, stiffness and specific stiffness (stiffness to weight) are important tonewood traits. With the increasing recognition of blackwood as a premium tonewood, a greater understanding of these wood properties will help identify the best blackwood for different tonewood applications, and hence for selection and breeding for these properties. Identifying genetic material that demonstrates stable wood property rankings across a range of sites will be important if gains in selection and breeding programs are to be fully realised.

The significant difference between the pure blackwood trials (Meunna, 266/2/2 and Virginstow, 266/4/2) clearly show that broad-scale environmental factors can affect blackwood basic density and GMC but potentially less so heartwood colour or TOF (Table 3). Significant environmental effects on basic density as well as heartwood colour in blackwood have previously been reported (Harrison 1975a; Harrison 1975b; Nicholas et al. 2007). Harrison (1975b) found no significant variation within but significant variation between regions in heartwood colour in blackwood plantations across South Africa. The environment that produced the best (dark and uniform) colour was a site well watered during the growing season but which had a definite dormant period induced by low rainfall and low temperatures as well as a frost period. The total amount of rainfall during the growing season was less important than the number of rain days. The results of Harrison (1975b) were not supported by Nicholas et al. (2007) who found significant differences in heartwood colour between two sites close together, assumed to have similar climates while three more distant sites, presumed to have greater differences in climate, were not significantly different in heartwood colour.

Nicholas et al. (2007) reported similar site differences for basic density to those found in this study, but did not identify rainfall differences as the possible cause. Higher basic density on drier sites has been observed in Acacia mangium (Awang and Taylor 1993) and E. globulus (Raymond and Muneri 2000), which is consistent with the present results as Virginstow is drier than Meunna. Downes et al. (2006) found a significant reduction in wood basic density in E. globulus and Eucalyptus nitens under irrigation that was not related to diameter growth. This is consistent with the current study where significant differences in basic density between trials were not associated with significant differences in diameter growth (Table 3). However, the lack of significant difference in basic density between the two Virginstow trials, despite a significant difference in wood GMC, suggests that factors other than moisture availability are also influencing blackwood basic density.

Mean heartwood colour values were within the range previously recorded (Nicholas et al. 1994; Bradbury 2005;
Nicholas et al. 2007). The significant trial, seedlot and interaction effects for all heartwood colour traits have been reported previously using different analyses (Bradbury et al. 2011) and demonstrate the complex nature of heartwood colour expression in blackwood. Mean and maximum measures of within-core variation $(\Delta E)$ showed no significant seedlot or trial effects, despite the significant effect of trial and seedlot on the linear change in heartwood colour reported previously (Bradbury et al. 2011). This suggests this methodology may have little power to detect biologically significant differences in within-tree colour variation. This lack of power may explain the absence of significant site and seedlot effects on within-tree colour variation in Calycophyllum spruceanum, which was examined using similar methods (Sotelo Montes et al. 2008).

The significant difference in heartwood colour between the two Virginstow trials was due to the presence or absence of the nurse crop. The only other differences detected between these trials were for green density and GMC. The presence of the nurse crop resulted in lighter, less yellow and less red wood as well as wood with lower GMC (also reflected in lower green density). This relationship between colour change and GMC associated with the presence of a nurse crop is unlikely to be causal and probably represents independent responses of the colour traits and GMC. This is due to the fact that: (1) there was no difference in heartwood colour between the two pure blackwood trials despite a significant difference in GMC of the wood (Table 3); (2) despite significant differences between seedlots in both heartwood colour and GMC there were no significant correlations between these traits at the seedlot level (Table 2); and (3) despite significant phenotypic correlations between GMC and the colour traits between trees within sites which were consistent with the nurse crop trends, the magnitude of the correlations was low $(r<0.16$; Table 2). So, while Harrison (1975b) reported that blackwood grown in South Africa on wetter sites produced darker wood, the present study suggests this is unlikely to be due to GMC per se. It is possible that the increased competition from the E. globulus nurse crop decreased the water available to the blackwood which affected the green moisture content of the wood, but these results suggest that other effects of competition or even allelopathy are responsible for the adverse effects on heartwood colour.

Figured blackwood, especially fiddleback, is in high demand (Lambert 2004). Little research has been done into the genetic or environmental control of figure in wood (Bragg et al. 1997), even less into techniques for sampling for figured wood. The reliability of stem cores for sampling for figure is therefore unknown. Fiddleback has been observed simultaneously on both the tangential and radial surfaces of blackwood timber. Stem cores may be more effective in detecting figure on the radial surface, depending 
upon the spatial extent and characteristics of the figure. That one core was observed to have fiddleback on the radial surface in this study indicates that this sampling technique may have some potential for future research into figured wood in live trees.

\subsection{Correlations}

Significant positive phenotypic correlations between diameter growth and percentage heartwood in this study support previous studies in blackwood (Nicholas et al. 1994; Nicholas et al. 2007) and demonstrate that at the phenotypic level, faster growing trees will produce more heartwood compared with sapwood. However, in the present study, the genetic-based differences between seedlots in this proportion were due to differences in the absolute amount of sapwood rather than heartwood. In the present study larger trees had higher GMC, but this relationship was not statistically significant in the study by Nicholas et al. (1994). The lack of significant genetic and phenotypic correlations between diameter growth and other important wood properties such as basic density and TOF (Table 2), suggests that increasing growth rates through either selection and breeding, or intensive management, should have little impact on these traits. This supports previous studies that have found no significant negative phenotypic correlations between diameter growth and basic density in blackwood (Nicholas et al. 1994; Bradbury 2005; Nicholas et al. 2007) and other Acacia species (Kim et al. 2008; Hai 2009). However, Hai (2009) found a significant negative genetic correlation between growth rate and wood stiffness measured on dried boards sawn from Acacia auriculiformis.

The green and basic densities were significantly positively correlated at the phenotypic and seedlot levels. There was a clear trend at both levels for wood with high basic density to have lower GMC, a trend also reported by Nicholas et al. (1994). Time of flight measurements on the standing trees were weakly negatively correlated with moisture content and green density but not basic density. There are no known comparable studies of TOF in blackwood with which to compare the present data. Yamamoto et al. (1998) measured standing tree radial (rather than longitudinal) TOF values for A. mangium. Significant positive correlations between standing tree TOF and wood density have been reported in A. mangium and other hardwood species (Yamamoto et al. 1998; Henson et al. 2004). As TOF is an indirect measure of wood stiffness, the significant seedlot variation in this trait and its apparent independence from basic density may be of potential interest in tonewood markets. The variation in blackwood basic density found in this and other studies, together with the apparent independent variation in wood stiffness found in this study, indicates the potential of blackwood to be used in a range of tonewood applications such as soundboards as well as back-and-side sets in acoustic guitars (Haines 2000; Wegst 2006; Morrow 2007).

The present study revealed a weak phenotypic association between growth rate and several aspects of heartwood colour. There was also a relationship between the percentage heartwood and several heartwood colour traits. Once this was accounted for there was only the tendency for larger trees to have more yellow heartwood that remained significant. Nicholas et al. (1994; 2007) found no significant phenotypic correlations between diameter growth and heartwood colour. However, in an independent study of native blackwood regrowth of variable age, Bradbury (2005) also reported a significant positive correlation of tree diameter and with heartwood yellowness $\left(b^{*}\right)$. A similar correlation has also been found in the Amazonian hardwood C. spruceanum (Sotelo Montes et al. 2008) but not in Eucalyptus dunnii (Vanclay et al. 2008) or teak (Tectona grandis) (Moya and Berrocal 2010). In all cases, correlations between diameter growth and heartwood colour were weak $(r<0.23)$, so that contrary to popular belief ( $\mathrm{p}$. 19, Morrow 2007), increased growth rate in blackwood does not lead to major changes in heartwood colour. However, there is a clear trend at the phenotypic (most significant) and family (only one significant) level for trees with greater percentage heartwood and greater basic and green density to have darker, redder and less yellow heartwood colour, all of which are favourable trends to meet general market requirements. These findings are consistent with those previously reported for basic density in blackwood (Nicholas et al. 1994) and C. spruceanum (Sotelo Montes et al. 2008).

A major issue for blackwood breeders and growers is the lack of information on market requirements for blackwood timber at the level of individual wood properties such as heartwood colour, basic density and wood stiffness. These requirements are likely to vary between market sectors, and change with consumer preferences. More market research is needed to allow breeders and growers to produce blackwood with more consistent wood properties better matched to market requirements.

Increasing blackwood growth rate under intensive management or through seedlot selection should result in increased heartwood production but have little effect on wood quality based on the traits assessed in this study. While significant site and seedlot effects were demonstrated for several important wood properties in this study, further advances will depend upon large scale sampling to better understand the effects of environment and genetics on their expression. At the environmental level, more sites need to be assessed as well as the impact of co-occurring species. Indeed, the finding that the nurse crop had an adverse effect on some wood properties needs further investigation so as 
to understand the mechanisms involved. It also means that the already complicated silviculture required in plantations with nurse crops is now confounded with potential adverse effects of the nurse crop on wood properties. At the genetic level, it is clear that greater sampling of the native range of blackwood is required to better understand the geographic trends in genetic variation and to estimate the genetic parameters such as heritabilities and genetic correlations required to predict the genetic gains achievable.

Acknowledgements We acknowledge assistance from Tim Davis and Philip Whiteaway in helping collect field data and David Clinch from Custom Cabinets, North Hobart in helping prepare stem cores for colour measurement.

Funding This research was funded by The Australian Research Council, project LP0562357 and supported by Forestry Tasmania, Private Forests Tasmania, Britton Timbers Tasmania, Forests and Forest Industry Council of Tasmania, Gunns Veneers and Corinna Sawmills.

\section{References}

Awang K, Taylor D (eds) (1993) Acacia mangium: growing and utilization. MPTS Monograph series no. 3. Winrock International and FAO, Bangkok, Thailand

Bolza E, Kloot NH (1963) The Mechanical Properties of 174 Australian Timbers. CSIRO Div For Prod tech paper no. 25

Bradbury GJ (2005) A comparison of timber quality of blackwood grown in young swamp forest, fenced regeneration, and a plantation. Tasforests 16:95-110

Bradbury GJ, Beadle CL, Potts BM (2010a) Genetic control in the survival, growth and form of Acacia melanoxylon. New For 39:139-156

Bradbury GJ, Potts BM, Beadle CL (2010b) Phenotypic variation in wood colour in Acacia melanoxylon R. Br. Forestry 83:153162

Bradbury GJ, Potts BM, Beadle CL, Dutkowski G, Hamilton M (2011) Genetic and environmental variation in heartwood colour of Australian blackwood (Acacia melanoxylon R.Br.). Holzforschung 65:349-359

Bragg DC, Mroz GD, Reed DD, Shetron SG, Stokke DD (1997) Relationship between "birdseye" sugar maple (Acer saccharum) occurrence and its environment. Can J For Res 27:1182-1191

Bucur V (2006) Acoustics of wood. Springer, Berlin

Cowan RS, Maslin BR (2001) Acacia melanoxylon. Flora of Australia Online. Australian Biological Resources Study, Canberra. Available at: http://www.environment.gov.au/biodiversity/abrs/onlineresources/flora/main/ Accessed 11 July 2011.

de Zwaan JG (1982) The silviculture of blackwood (Acacia melanoxylon). S Afr For J 121:38-43

Downes G, Worledge D, Schimleck L, Harwood C, French J, Beadle C (2006) The effect of growth rate and irrigation on the basic density and kraft pulp yield of Eucalyptus globulus and E. nitens. NZ J For 51:13-22

Evans P (2007) The use of blackwood in the Australian guitarmaking industry. In: Beadle C. L. and Brown A. G. (eds) Acacia utilisation and management: adding value-3rd Blackwood Industry Group (BIG) workshop, Marysville, VIC, 2629 April 2006. RIRDC Publ no. 07/095, Canberra, Australia, pp. $45-46$
Grabianowski M, Manley B, Walker J (2006) Acoustic measurements on standing trees, logs and green lumber. Wood Sci Tech 40:205216

Grant JC (1995) Forest soils of Tasmania: a handbook for identification and management. Forestry Tasmania, Hobart

Hai PH (2009) Genetic improvement of plantation-grown Acacia auriculiformis for sawn timber production. Ph.D. thesis, Swedish University of Agricultural Sciences, Uppsala

Hai PH, Jansson G, Harwood C, Hannrup B, Thinh HH, Pinyopusarerk K (2007) Genetic variation in wood basic density and knot index and their relationship with growth traits for Acacia auriculiformis A. Cunn ex Benth in Northern Vietnam. In: 1st Australasian forest genetics conferencebreeding for wood quality, Hobart, Tasmania, Australia, 11-14 April 2007

Haines DW (2000) The essential mechanical properties of wood prepared for musical instruments. Catgut Acoust Soc J 4:20-32

Harrison CM (1975a) The relative influence of genetics and environment upon certain timber quality characteristics of Acacia melanoxylon in South Africa. For S Afr 17:23-27

Harrison CM (1975b) Heartwood colour patterns in South African Acacia melanoxylon. For S Afr 17:49-56

Haslett AN (1986) Properties and utilisation of exotic speciality timbers grown in New Zealand. Part II, Australian blackwood (Acacia melanoxylon R. Br.). Bulletin no. 119, Forest Research Institute, Rotorua

Henson M, Boyton S, Davies M, Joe B, Kangane B, Murphy TN, Palmer G, Vanclay JK (2004) Genetic parameters of wood properties in a 9 year old E. dunnii progeny trial in NSW, Australia. In: International IUFRO conference: eucalyptus in a changing world, Aveiro, Portugal, 11-15 October 2004

Kim N, Ochiishi M, Matsumura J, Oda K (2008) Variation in wood properties of six natural acacia hybrid clones in northern Vietnam. J Wood Sci 54:436-442

Kingston RST, Risdon C (1961) Shrinkage and density of Australian and other woods. CSIRO Div For Prod technological paper no. 13, Melbourne, Australia

Lambert J (2004) Blackwood features in demand: a Victorian case study. In: Brown A. G. (ed) Blackwood management-learning from New Zealand-2nd Blackwood Industry Group (BIG) workshop, Rotorua, New Zealand, 22 November 2002. RIRDC Publication no. 04/086, Canberra, pp. 42-45

Morrow A (2007) Evaluation of Australian timbers for use in musical instruments, JW Gottstein Memorial Trust Fund, Clayton South, VIC

Moya R, Berrocal A (2010) Wood colour variation in sapwood and heartwood of young trees of Tectona grandis and its relationship with plantation characteristics, site, and decay resistance. Ann For Sci 67:109

Nicholas ID, Dungey H, Gifford HH, Cox J, Hodgkiss P, Jones T (2007) Preliminary analysis of the wood properties of Acacia melanoxylon thinnings from five North Island regime trials in New Zealand. In: Beadle C. L. and Brown A. G. (eds) Acacia utilisation and management: adding value-3rd Blackwood Industry Group (BIG) workshop, Marysville, VIC, 26-29 April 2006. RIRDC publication no. 07/095, Canberra, Australia. pp. 14-20

Nicholas ID, Young GD, Gifford HH (1994) Wood properties of Acacia melanoxylon: variation within and between four seedlots. In: Faces of farm forestry, proceedings of the Australian forest growers conference, Launceston, Tasmania, Australia. Australian Forest Growers, Braddon, ACT, Australia, pp. 105-110

Quinn GP, Keough MJ (2002) Experimental design and data analysis for biologists. Cambridge University Press, Cambridge

Raymond C, Muneri A (2000) Effect of fertilizer on wood properties of Eucalyptus globulus. Can J For Res 30:136-144 
SAS Institute Inc. (2004) SAS/STAT ${ }^{\circledR} 9.1$ User's Guide, SAS Institute, Cary, NC, USA

Searle SD, Owen JV (2005) Variation in basic wood density and percentage heartwood in temperate Australian Acacia species. Aust For 68:126-136

Sotelo Montes C, Hernández R, Beaulieu J, Weber J (2008) Genetic variation in wood color and its correlations with tree growth and wood density of Calycophyllum spruceanum at an early age in the Peruvian Amazon. New For 35:57-73
Vanclay J, Henson M, Palmer G (2008) Color variation and correlations in Eucalyptus dunnii sawnwood. J Wood Sci 54: $431-435$

Wegst UGK (2006) Wood for sound. Amer J Bot 93:1439-1448

Wyszecki G, Stiles WS (1982) Color science: concepts and methods, quantitative data and formulae. Wiley, New York

Yamamoto K, Sulaiman O, Hashim R (1998) Nondestructive detection of heart rot of Acacia mangium trees in Malaysia. For Prod J 48:83-86 